\title{
Kebijakan Peningkatan Pemberian ASI Eksklusif
}

\section{Helda*}

\begin{abstract}
Abstrak
Angka Kematian Bayi di Indonesia adalah 35/1000 kelahiran hidup berada di posisi keenam di negara Asean. Salah satu upaya yang efisien untuk menurunkan angka kematian tersebut adalah pemberian ASI eksklusif yang memperlihatkan tren yang menurun, pada tahun 1997, (40,2\%), 2002 (39,5\%) dan 2007 (32\%). Artikel ini bertujuan mengkaji kebijakan pemerintah memenuhi hak anak terhadap ASI. Metode yang digunakan melakukan telaah berbagai studi tentang kebijakan dan perundangan ASI di dunia dan di Indonesia,pada periode 2000-2007. Angka ASI eksklusif di dunia sangat bervariasi dan tidak berbanding lurus dengan kemajuan suatu negara. Jepang dan Inggris adalah contoh negara maju dengan angka ASI eksklusif yang rendah. Susu formula, sosial budaya dan wanita bekerja menjadi alasan pemakaian susu formula yang rendah. Di Indonesia, kasus balita gizi buruk pada tahun 1989, (75/10.000) dan pada tahun 2002 (70,3/ 10.000) memperlihatkan tren penurunan yang rendah. Meskipun manfaat ASI dirasakan oleh semua pihak, tetapi angka pemberian ASI masih tergolong rendah, sementara pemasaran susu formula, sosial budaya, dan wanita bekerja tidak mendukung pemberian ASI. Di Indonesia hanya ada 2 keputusan menteri kesehatan (237/1997 dan 450/2004) yang mengatur pemberian ASI. Kebijakan yang ada belum mampu mengatasi angka pemberian ASI yang rendah. Disarankan untuk meningkatkan status hukum kebijakan yang ada dan mengupayakan peningkatan komitmen.
\end{abstract}

Kata kunci : ASI eksklusif, kebijakan, susu formula.

\begin{abstract}
Infant mortality rate in Indonesia (35/1000 life birth) is one of the poorest (ranked number six) among ASEAN countries. One known efficient measure for reducing the infant mortality rate is exclusive breast feeding (EBF) which in fact showing a decreasing trend (40.2\% in $1997,39.5 \%$ in 2002 and $32.0 \%$ in 2007 ). The objective of this article is to evaluate government policy regarding the fulfillment of child's rights to get adequate breastfeeding. The method used is by literature review of studies about breast feeding policy and regulations in the world and in Indonesia, during the period of 2000-2007. The EBF rates in the word are varied and not related to the developmental level of the country. Japan and England are examples of developed countries with low EBF rate. Formula milk, sosio-cultural, and working women are the most reasons of the low rate of EBF. In Indonesia, the cases of malnutrition among children under five years in 1989 (75/10.000) and in 2002 (70, 3/ 10.000 showed a decreasing trend. Although the benefit of the breastfeeding is known by almost all people, but the EBF rate is still low. Meanwhile, formula milk marketing, sosio-cultural aspects, and the phenomenon of increasing number of working women do not support EBF. In Indonesia, there are only two ministry regulations (237/1997 and 450/2004) that regulated EBF. The existing policies are not strong enough to solve the problem of low EBF rate. It is suggested to improve the legal aspects including policy and regulations as well as improvement in government commitment to support EBF.
\end{abstract}

Key words : Exclusive breast feeding, policy, formula milk. 
Angka Kematian Bayi (AKB) merupakan salah satu indikator yang digunakan dalam menentukan derajat kesehatan suatu negara. AKB Indonesia masih menempati posisi rendah di kalangan negara-negara ASEAN. Dengan 35/1000 Kelahiran Hidup (KH), Indonesia menempati urutan keenam. Negara-negara yang berada di atas Indonesia adalah Singapura (3/1000), Brunei Darussalam (6/1000), Malaysia (8/1000), Philipina(29/1000), Thailand (24/1000), dan Vietnam (30/1000). Sedangkan Negara yang berada di bawah Indonesia adalah Myanmar (7/1000), Laos (87/1000) dan Kamboja (96/1000). ${ }^{1}$

Dalam upaya menurunkan angka kematian tersebut, berbagai upaya dilakukan, seperti imunisasi, persalinan dengan nakes, pemberian ASI segera dan eksklusif. Upaya pencegahan terhadap penyakit infeksi dapat dilakukan apabila kondisi gizi dalam keadaan baik. Salah satu upaya agar gizi bayi tetap prima adalah dengan mendapat ASI sedini mungkin dan eksklusif. Air Susu Ibu (ASI) memegang peranan penting dalam menjaga kesehatan dan kelangsungan hidup bayi. Awal menyusui yang baik adalah sesegera mungkin, yaitu 30-60 menit pertama setelah kelahiran. Isapan bayi pada puting ibu bukan bertujuan memperoleh ASI yang banyak. Tujuan yang lebih penting adalah adanya rangsangan produksi ASI dan kalau kolustrum sudah keluar maka akan diperoleh hanya dalam beberapa tetes.

Kontak awal dan menyusui dini akan memberikan manfaat bagi ibu dan bayi. Ibu yang kontak dan menyusui segera setelah melahirkan akan mempercepat pelepasan plasenta, memperkecil rahim dan mencegah perdarahan pasca persalinan. Bayi memiliki peluang lebih besar untuk menyusui eksklusif dan lebih lama dibandingkan dengan yang tidak. Bayi yang diletakan di perut ibu segera setelah lahir akan bergerak ke arah puting payudara ibu. Hal ini merupakan rangsangan terhadap refleks yang ada pada bayi. Tetapi, pada bayi yang diberikan susu botol maka refleks ini akan berkurang bahkan bisa hilang hingga $100 \% .^{2}$

Walaupun para ibu sudah mengetahui manfaat ASI yang sangat banyak, namun pemberian ASI masih rendah. Hasil survei SDKI 1997-2007 terlihat penurunan pemberian asi eksklusif, yaitu $40,2 \%$; $39,5 \%$; dan $32 \%$ bayi di Indonesia yang memperoleh ASI eksklusif sedangkan pemberian ASI pada bayi umur kurang dari 2 bulan sebanyak $64 \%$; antara $2-3$ bulan $45,5 \%$; antara $4-$ 5 bulan $13,9 \%$ dan antara $6-7$ bulan 7,8\%. Sementara itu cakupan pemberian susu formula meningkat 3 kali lipat dari 1997 sebesar 10,8\% menjadi 32,4\% pada tahun 2002.1,3,4

Faktor yang mempengaruhi seorang ibu akan memberikan ASI eksklusif, seperti perilaku menyusui yang kurang dapat dukungan, pemberian makanan dan minuman sebelum ASI keluar, ibu kurang percaya diri kalau
ASI-nya cukup untuk bayi, ibu kembali bekerja, dan gencarnya promosi susu formula. Selain itu, sikap petugas kesehatan yang kurang mendukung, lemahnya perencanaan terpadu PP-ASI, dan seringnya tejadi pergantian personil yang berdampak terhadap program PP-ASI. Lagipula, lemahnya sanksi pelaksanaan Rumah Sakit Sayang Bayi (RSSB) berdampak hanya 25\% yang masih RSSB, kurangnya integrasi dalam kurikulum tenaga kesehatan dan lintas sektor mnyebabkan kendala dalam program PP-ASI. ${ }^{5}$

Hal ini memperihatkan kegagalan pemerintah menjamin kesehatan dan kesejahteraan penduduk yang termaktub dalam pasal 28 UUD 1945 khususnya pasal 28 B ayat 2 yang menyatakan "setiap anak berhak atas kelangsungan hidup, tumbuh dan berkembang serta berhak atas perlindungan dari kekerasan dan diskriminasi”. Disamping itu, UU No. 23 Tahun 2002 tentang perlindungan anak yang mengacu pada konvensi hak-hak anak menyebutkan "setiap anak berhak untuk dapat hidup, tumbuh, berkembang dan berpartisipasi secara wajar sesuai dengan harkat dan martabat kemanusiaan serta mendapat perlindungan dari kekerasan dan diskriminasi”. Didasari hal tersebut perlu dikaji kebijakan pemerintah yang ada dalam rangka pemenuhan hak anak terhadap ASI segera dan eksklusif. Apakah nilai yang ada saat ini tentang ASI hak semua bayi sudah memenuhi trias kebijakan yaitu equity, efisien dan efektif.6-8

\section{ASI Eksklusif}

ASI eksklusif atau lebih tepat disebut pemberian ASI secara eksklusif adalah kondisi bayi yang hanya diberi ASI tanpa tambahan cairan lain seperti susu formula, jeruk, madu dan air teh, air putih tanpa tambahan makanan padat seperti pisang, pepaya, bubur susu, bubur nasi dan tim. Sesungguhnya, memberikan ASI adalah cara memberikan makanan bayi secara alamiah. Namun, sering kali ibu-ibu kurang mendapat informasi bahkan sering kali dapat informasi yang salah tentang pemanfaatan ASI eksklusif, tentang bagaimana menyusui yang benar dan apa yang harus dilakukan bila timbul masalah saat memberikan ASI. ${ }^{9}$

Perkembangan zaman menuntut kehidupan yang lebih kompetitif sehingga wanita lebih banyak bekerja untuk memenuhi kebutuhan hidup keluarganya. Sesuai kodratnya, pekerja wanita juga akan mengalami haid, kehamilan, melahirkan dan menyusui namun, mereka diperlakukan sama. Memberikan ASI menjadi pada ibu bekerja merupakan masalah belum bisa diatasi dengan baik karena tempat kerja para ibu yang menyusui belum ramah terhadap bayi. Susu formula jadi solusi yang sangat tepat bagi mereka karena keadaan tersebut. ${ }^{10}$

\section{Manfaat Pemberian ASI}

Pemberian ASI segera dan eksklusif memberikan 
manfaat pada ibu, bayi dan lingkungannya. ASI bagi bayi merupakan sumber nutrisi. Komposisi ASI berbeda dan disesuaikan dengan kondisi bayi. ASI kolostrum mengandung antibodi yang sangat dibutuhkan bayi untuk menggantikan antibodi yang diperoleh dari ibu. Antibodi dari ibu akan segera turun cepat sekali segera setelah bayi lahir. Sementara itu, badan bayi mampu membuat zat kekebelan cukup banyak pada saat berusia 9-12 bulan. Bayi yang mendapat ASI akan lebih cerdas. Mengingat kecerdasan anak berkaitan erat dengan otak maka jelas perkembangan kecerdasan dipengaruhi oleh perkembangan otak. Faktor yang penting pada perkembangan otak adalah nutrisi yang diberikan. Kesempatan mendapatkan ASI segera dan eksklusif jelas sekali berhubungan dengan perkembangan otak sekaligus perkembangan kecerdasan. Manfaat lain bagi bayi adalah meningkatkan jalinan kasih sayang ibu dan bayi serta menunjang kepribadian yang cerdas, emosional dan kematangan spritual. ${ }^{9}$

Ibu yang memberikan ASI nya akan turun risiko terjadinya pendarahan, anemia, terkena kanker. Jarak kehamilan menjadi jarang, rahim cepat mengecil, cepat langsing karena proses menyusui yang dilaksankan segera dan eksklusif sampai dua tahun atau lebih. Pemberian ASI juga berdampak ekonomis, tidak merepotkan, hemat waktu, portabel, praktis dan memberi kepuasan pada ibu. ${ }^{10}$ Bayi yang diberi ASI oleh ibunya akan lebih sehat dibandingkan yang tidak diberi ASI. Hal ini berdampak pada ibu yang bekerja. Ibu bekerja akan jarang bolos karena alasan anak sakit. Jadi, pemberian ASI menyebabkan ibu lebih bisa berkonsentrasi bekerja dan berpeluang untuk meningkatkan prestasi kerjanya. Bagi negara, pemberian ASI menghemat devisa negara. Pengehematan devisa untuk membeli susu formula, penghematan biaya sakit pada bayi dan ibu. Menciptakan generasi yang tangguh dan menghindari lost generation. Pemberian ASI sangat ramah lingkungan. Dengan memberikan ASI tak perlu ada kaleng, karton, botol, dot bekas. Di Amerika Serikat dalam satu tahun terdapat 550 juta kaleng susu. Bila kaleng ini dijajarkan maka akan mengelilingi dunia. Pemberian ASI akan mengurangi polusi udara yang keluar dari pabrik susu formula. ${ }^{9}$

Direktur Gizi Masyarakat Departemen Kesehatan mengungkapkan, jika semua bayi diberi susu formula sampai usia enam bulan dibutuhkan dana 3,960 triliun rupiah. Hal ini berdasarkan jika ada 4,5 juta bayi mendapatkan 44 kaleng susu formula seharga 20.000 rupiah. ${ }^{8}$ Menurut Yeong Jookean, perdagangan susu merupakan bisnis dengan keuntungan luar biasa. Setahun bisa mencapai US\$11 milyar. Padahal, jika seorang ibu menyusui bayi maka ibu dapat menghemat uang sebesar Rp.300.000,- setiap bulan. Selain itu dengan memberikan ASI eksklusif selama 6 bulan maka gizi bayi akan cukup, tak terjadi kurang gizi. Secara global empat juta bayi meninggal pada bulan pertama.
Berdasarkan jumlah tersebut $60 \%$ disebabkan karena kurang gizi. ${ }^{11}$

\section{Kebijakan ASI Eksklusif \\ Amerika Serikat}

Kebijakan ASI ekslusif di negara bagian Amerika Serikat (AS) sangat bervariasi. Kebijakan ASI yang dijalankan dalam 6 tahun terakhir ini telah berbentuk undang-undang di 1/3 negara bagian AS. Namun, masih banyak negara bagian AS yang menundanya karena berbagai sebab. Ada perbedaan antara negara bagian AS dalam menanggapi kebijakan WHO ini, mulai dari sekedar membuat kebijakan sederhana sampai membuat undang-undang Rumah Sakit Sayang Bayi. Umumnya masalah yang terkait dengan pemberian ASI di AS adalah tidak adanya tempat menyusui di tempat-tempat umum, seperti sekolah, kolam renang, restoran, toko, dan lainlain. Ada yang berpendapat hal ini adalah perbuatan tidak senonoh, melanggar aturan institusi, dan lain-lain. Ada masalah diskriminasi terhadap ibu yang menyusui. Ibu menyusui yang berada di tempat umum tidak dapat memberikan ASI nya karena tak ada payung hukum yang melindunginya. ${ }^{12}$ Beberapa negara bagian AS mencoba membuat undang-undang tentang masalah ini. Negara bagian seperti Florida, Utah, New York, Philadelpia, Illinois, mencoba membuat baru atau mengamandemen undang-undang tentang dukungan terhadap ibu menyusui. Harapannya dengan adanya aspek legal ini ibu yang menyusui dalam memberikan ASInya dalam segala situasi.

Di Illinois, istri Gubernur Rod R. Blagojevich tahun 2004 menandatangani rancangan Undang-undang No. 3211 tentang Hak untuk Menyusui. Menurut ibu Patti Blagojevich, hukum ini adalah langkah penting dalam rangka mendukung pemberian ASI. Hukum baru ini akan melindungi ibu yang ingin menyusui anaknya. ${ }^{13}$ Berbagai kasus muncul mendahului hadirnya undangundang ASI eksklusif ini. Misalnya, kasus ibu yang menyusui adalah seorang guru sekolah 'Dike v. Orange Country School Board'. Dia dilarang menyusui karena ada aturan sekolah melarang guru membawa anak ke sekolah atau pulang untuk menyusui. Pengadilan perlu mempertimbangkan hak individu dan kepentingan pemerintah. ${ }^{14}$

Masalah lain adalah perdagangan susu formula yang marak. Walaupun promosi ASI eksklusif telah dilaksanakan seoptimal mungkin namun persentase ibu yang memberikan ASI nya masih rendah terutama pada ibu yang masih muda. Keputusan untuk menggunakan susu formula dipengaruhi oleh iklan yang ditayangkan dan hadiah yang diberikan pada ibu pasca bersalin. Kepada tenaga kesehatan produsen susu formula memberikan bermacam-macam hadiah dalam rangka meningkatkan penjualan susu formula. Massachusetts, 
menjadi negara bagian AS pertama yang melarang pemberian hadiah dari susu formula dalam rangka mendukung ASI eksklusif. Awalnya Dewan Kesehatan Masyarakat menunda kebijakan tersebut untuk dipelajari selama 3 bulan. Walaupun manfaat ASI eksklusif telah diketahui secara luas namun tak mudah untuk mempopulerkannya. ${ }^{14}$

Kebijakan menunda pelarangan pemberian susu formula pada ibu menyusui karena ada intervensi oleh Gubernur Massachusetts Mitt Romney. Karena itu, Dewan Kesehatan Masyarakat memperbolehkan rumah sakit melanjutkan partisipasinya dalam kampanye susu formula. Keputusan yang kontroversi ini menyebabkan Eksekutif Direktur APHA (The American Public Health Association) perlu membuat surat kepada Gubernur Massachusetts memintanya untuk mempertimbangkan keputusan tersebut. ${ }^{14,15}$

Setelah melewati perdebatan panjang, para pendukung ASI eksklusif menyatakan, bahwa mereka tidak hanya ingin memperjuangkan ASI eksklusif saja tetapi juga larangan penggunaan rumah sakit sebagai tempat pemasaran susu formula. Sebelas rumah sakit di Kota NewYork mulai melaksanakan larangan pemberian susu dalam bentuk sachets dalam tas yang diberikan saat kepulangan bayi. Kemudian rumah sakit di Massachusetts dan California ikut bergabung dalam pelarangan ini. ${ }^{16}$ Koalisi breastfeeding Massachusetts menyatakan ada 7 organisasi kesehatan Amerika dan WHO menyatakan siap memerangi distribusi susu formula dalam tas yang diberikan saat ibu dipulangkan. Pernyataan ini diperlukan dalam rangka mendukung program pemberian ASI. ${ }^{17}$

Hambatan lain yang jadi masalah dalam pemberian ASI adalah ibu bekerja. Negara bagian AS yaitu Texas dan Florida telah mengembangkan dukungan menyusui pada ibu bekerja. Florida membuat undang-undang tentang menyusui pada ibu bekerja. Aturan ini kurang dapat perhatian dari pemerintahan, bahkan untuk pegawai negeri sekalipun. Namun, Texas lebih inovatif, negara bagian ini menjadi negara pertama yang menyediakan insentif bagi perusahaan swasta yang mendorong ibu untuk tetap melanjutkan pemberian ASI nya setelah masa cuti berakhir. ${ }^{13}$

\section{Filipina}

Menurut Badan Kesehatan Dunia (WHO), Filipina menempati posisi terendah dalam jumlah ibu yang menyusui anaknya. Perusahaan susu formula sangat berpengaruh di sana. Pemerintah mencoba melarang perusahaan susu formula mengiklankan produk mereka. Hal ini menimbulkan kekhawatiran bagi perusahaan susu formula, sehingga kebijakan baru ini dibawa ke Makhamah Agung. Kamar Dagang Amerika Serikat memperingatkan aturan lokal tersebut dapat berdampak buruk terhadap investasi Amerika. Namun, dr. Jean Marc Olive mengatakan ini bukan masalah bisnis tapi masalah nyawa manusia. ${ }^{18}$ Dalam rangka kampanye ASI, UNICEF mengelar acara pemecahan rekor jumlah ibu menyusui bayi pada saat yang bersamaan di Filipina. $3.869 \mathrm{ibu}$ ambil bagian dalam acara pemecahan rekor ini tahun lalu gelaran yang sama juga diadakan di Filipina. Tahun lalu pesertanya 3.738 dimana mengalahkan ibuibu di Berkley California sebanyak1.135 orang. ${ }^{19}$

\section{Jepang}

Angka menyusui di Jepang sangat rendah dibandingkan dengan negara maju lainnya. Bayi usia 1-2 bulan hanya $44,8 \%$ yang disusui sementara itu AS sekitar $54,7 \%$ pada usia 1 bulan dan Swedia $80,2 \%$ pada usia 2 bulan. Studi yang lain memperlihatkan bahwa bayi usia 3-6 bulan hanya $43,8 \%$ yang diberikan ASI sebagai perbandingan di AS angka ASI nya 47\% pada usia bayi 3 bulan. Pasangan Jepang cenderung untuk tidak memiliki keturunan atau hanya sedikit keturunan. Hal ini disebabkan mahalnya biaya hidup dan harapan sosial yang tinggi. Belum ada kebijakan yang diambil pemerintah Jepang. Perdana Mentri Shinzo Abe mengatakan kuncinya adalah reformasi pendidikan. Pemerintah merencanakan meningkatkan perawatan anak, promosi persamaan gender, dan mendorong perusahaan untuk memberikan kesempatan yang luas bagi karyawannya untuk tanggung jawab keluarga. ${ }^{19}$

\section{Inggris}

Kebijakan yang diambil pemerintah Inggris mempromosikan pemberian ASI dengan memberikan voucher kepada ibu yang menyusui golongan ekonomi rendah. Voucher bisa ditukar dengan buah-buahan senilai voucher tersebut. Kebijakan ini didasari pada efisiensi. Pemerintah menghabiskan 35 juta poundsterling/tahun untuk mengobati gastroenteritis karena susu botol. Tiap peningkatan $1 \%$ peningkatan pemakaian ASI selama 13 minggu akan menghemat sebesar 500.000 poundsterling. Namun, kebijakan ini dapat tantangan dari parlemen karena ada diskriminasi status sosial ekonomi pada ibu yang menyusui bila voucher ini diberlakukan. Pemerintah membuat berbagai strategi untuk mempromosikan ASI, namun di pihak lain pabrik susu formula menghabiskan 4-5 juta pondsterling untuk promosi susu formula. Iklan susu formula pada bayi memang area yang kontroversi. Rekomendasi WHO dan UNICEF "tak ada iklan susu formula untuk bayi”, namun pemerintah Inggris memberikan izin iklan pada bayi 6 bulan keatas.

Depkes Inggris mendanai 15.000 pondsterling promosi ASI tahun 1988. Tiga bulan program pemberian voucher ini berjalan berdampak peningkatan rate ASI naik 34\% menjadi 44\%. Hasil survei 1995 memperlihatkan $97 \%$ para ibu mengharapkan adanya tempat yang 
nyaman untuk menyusui. Tahun 1994 WHO dan UNICEF mencanangkan rumah sakit sayang bayi. Hanya 69 RS yang dapat sertifikat RS Sayang Bayi. Penelitian di Inggris memperlihatkan bahwa ibu yang melahirkan di RS tidak menambah durasi ASI. Kalau mau membuat Rumah Sakit Sayang Bayi sebaiknya di tempat yang penggunaan ASI nya rendah. Memang pada Rumah Sakit Sayang Bayi adalah awal yang baik untuk promosi penggunaan ASI tapi tidak langgeng kecuali dengan kunjungan rumah. 20

\section{Indonesia}

Indonesia pada tahun 2002 jumlah penduduk meningkat menjadi 208.749. 460 dan jumlah balita gizi buruk 1.469.596 jiwa. Tahun 2003 IPM Indonesia menempati urutan 112 dari 175 negara, selain itu tiap menit ada 2 balita yang meninggal. ${ }^{21}$ Peningkatan pemberian ASI merupakan salah satu cara untuk menurunkan angka kesakitan dan kematian bayi serta gizi buruk pada balita. Pemberian ASI eksklusif pada semua bayi Indonesia tentu akan meningkatkan kesehatan bayi Indonesia. Pada gilirannya akan meningkatkan IPM. Oleh karenanya, sangat penting membuat kebijakan yang mendukung pemberian ASI eksklusif.

Pemerintah Indonesia mengeluarkan 2 keputusan Menkes sebagai penerapan kode etik WHO dalam pemberian ASI dan pemasaran susu formula. Pada keputusan tersebut dicantumkan pemberian ASI eksklusif, yaitu pada Permenkes Nomor 450/Menkes/SK/IV/2004. Pemerintah juga mengatur tentang makanan pemasaran susu formula dalam Kepmenkes Nomor 237/1997.

Menurut Direktur Gizi Masyarakat Departemen Kesehatan, pemberian ASI yang masih rendah disebabkan oleh pengaruh penggunaan susu formula akibat promosi susu formula yang gencar. Masalahnya belum ada sanksi yang jelas, sehingga banyak pelanggaran kode etik pemasaran susu formula. Pelanggaran terhadap kebijakan pemasaran susu formula tersebut, berupa pemberian sampel susu formula ke fasilitas kesehatan. Bahkan disinyalir ada kerja sama antara produsen susu formula dan fasilitas kesehatan. Akibatnya, bayi yang baru lahir langsung diperkenalkan dengan susu formula bukan dengan ASI yang mempunyai banyak manfaat.

Berdasarkan SDKI tahun 1997 dan 2003, angka pemberian ASI eksklusif turun dari 49\% menjadi 39\% sedangkan penggunaan susu botol meningkat 3 kali lipat. Menurut survei Hellen Keller Internasional rata-rata bayi Indonesia hanya 1,7 bulan yang mendapatkan ASI eksklusif. Hal ini tentu berdampak pada status gizi bayi dan angka kematian bayi. Masalahnya saat otonomi daerah membuat daerah propinsi dan kabupaten/kota tidak merasa wajib mematuhi peraturan yang dikeluarkan Menkes. Selain itu, fasilitas kesehatan butuh dana. Produsen butuh pasar dan konsumen tak paham bisnis.
Pasangan yang melahirkan tak paham pentingnya ASI dan masyarakat tak tahu peraturan tentang ASI.22,23

Dua peraturan Menkes yang ada sifatnya tidak mengikat, sehingga diperlukan mengadopsi ketetapan yang sudah dibuat WHO tentang kode etik pemasaran susu formula ke dalam undang-undang. Rencana ini sudah dipikirkan dengan membuat Rancangan Peraturan Pemerintah (RPP) tentang pengaturan promosi dan pemasaran susu formula. Namun, saat ini RPP yang tengah dibahas tersebut berubah dari RPP pemasaran susu formula menjadi RPP pemberian ASI, dikhawatirkan PP ini tidak mampu menjadi landasan untuk menindak pelanggaran yang terjadi selama ini. Masalah yang menghambat adopsi kode etik WHO tersebut antara lain kurang komitmen, keterbatasan aksi, perubahan kepemimpinan negara, kurang apresiasi, sikap petugas kesehatan, serta pertimbangan politik,ekonomi dan sosial. 24

Depkes membuat strategis Nasional Peningkatan Pemberian ASI pada Pekerja Wanita. Peningkatan pemberian ASI pada pekerja wanita. Data BPS tahun 2003 pekerja Indonesia mencapai 100.316.007 dimana $64,63 \%$ pekerja laki-laki dan $35,7 \%$ pekerja wanita. Mengingat pentingnya pemberian ASI bagi tumbuh kembang yang optimal baik fisik maupun mental dan kecerdasan maka perlu pertimbangan agar para ibu dapat memberikan ASI nya dengan benar termasuk ibu yang bekerja.

Ibu yang bekerja sangat singkat masa cutinya dan beragam lapangan pekerjaannya. Hal ini tentunya kendala bagi ibu yang bekerja untuk memberikan ASI eksklusif. Oleh karena itu, diperlukan rencana yang strategis agar ibu memberikan ASI secara eksklusif. Langkah-langkah kegiatan yang dilakukan pemerintah adalah mengembangkan KIE, menggerakkan pengusaha, meningkatkan keterpaduan, koordinasi dan integrasi serta mengembangkan tempat penitipan anak. ${ }^{25}$

\section{Kesimpulan}

ASI dirasakan manfaat oleh bayi, ibu, keluarga, masyarakat dan negara. Kendala dalam pemberian ASI adalah susu formula, sosial budaya dan wanita bekerja. Namun, telah ada kebijakan yang merespon ASI eksklusif, kode etik pemasaran susu formula dan peningkatan ASI pada pekerja wanita. Kebijakan yang ada belum bersifat mengikat sehingga perlu peningkatan status hukum kebijakan tersebut. Belum ada komitmen yang kuat untuk melaksanakan ASI eksklusif.

\section{Saran}

Perlu peningkatan status hukum kebijakan ASI yang sudah ada. Penegakkan hukum dibutuhkan dalam rangka meningkatkan komitmen peningkatan penggunaan ASI. Rancangan Peraturan Pemerintah sebaiknya diganti dengan Undang-undang dimana mewajibkan semua bayi 
mendapatkan ASI eksklusif kecuali kondisi tertentu, ibu meninggal, bayi bibir sumbing atau yang lainnya. Selain itu perlu dibuat aturan yang melarang pemasaran dan penjualan susu formula umur 0-6 bulan secara bebas.

\section{Daftar Pustaka}

1. Badan Pusat Statistik, BKKBN, Departemen Kesehatan. Survei demografi dan kesehatan Indonesia 2002-2007. Jakarta: Badan Pusat Statistik; 2003.

2. Prasetyo S. Pekan air susu ibu (ASI) sedunia campur tangan suami, hasilkan ASI lebih banyak. Jakarta: Sinar Harapan; 2003 [edisi 2003]. Diunduh dari: http://www.sinarharapan.co.id.

3. Sistem Informasi Kesehatan Kota Blitar. Hanya 3.7\% bayi memperoleh ASI [edisi 2007]. Diunduh dari: http://www.sikonline.net.

4. Redaksi. Turun, jumlah bayi yang dapat ASI eksklusif [edisi 2007]. Diakses dari: http://www.keluargasehat.com.

5. Departemen Kesehatan RI. Strategi nasional PP-ASI [edisi 2007]. Diunduh dari: http://www.gizi.net/kebijakan-gizi/download/starnas\%0final.doc

6. Sekretariat Jendral MPR RI, Undang-undang dasar negara republik Indonesia tahun 1945. Jakarta: Perum Percetakan Negara; 2002.

7. Makhamah Konstitusi RI, Undang-undang dasar negara republik Indonesia tahun 1945. Jakarta: Perum Percetakan Negara; 2006.

8. WHO, UNIKCEF, dan IDAI. Rekomendasi pemberian makan bayi pada situasi darurat. Jakarta: WHO, UNIKCEF, dan IDAI; 2005.

9. Utami, R. Mengenal ASI eksklusif. Jakarta: Trubus Agriwidya; 2000.

10. Suradi R. Menejemen laktasi perkumpulan perinatologi Indonesia. Jakarta; 2007

11. Hak bayi dirampok pengusaha susu formula [edisi 22 Agustus 2003]. Diunduh dari: www.suarapembaruan.com.

12. State of Illinois. Governor Blagojevich signs right to breastfeed act new law allows for breastfeeding in public places [edisi 2007]. Diunduh dari: http://www.paho.org.

13. Baldwin EN. A look at enacting breastfeeding legislation [edisi 2006]. Diunduh dari: http://www.lalecheleague.org/law/lawenact.html.
14. Johnsons TD. Massachusets ban on formula samples supports breastfeeding. Washington: The Nation's Health; 2006 [edisi Mei 2006]. Diunduh dari: http://www.proquest.umi.com.

15. Arias DC. Massachusets will allow formula bags. Washington: The Nation's Health; 2006 [edisi Agustus 2006]. Diunduh dari: http://www.proquest.umi.com

16. Zimmerman R. Baby goody bags may be on the way out; some hospitals, cities bow to breast-feeding camp, irking formula markers. Wall Street Journal. Februari 2007 [edisi Februari 2007]. Diunduh dari: http://www.proqust.umi.com.

17. Masshachusetts Breastfeeding Coalition. Organization that have made statements opposing hospital-based distribution of free commercial formula discharge bags. Petitions fact sheet [edisi 2007]. Diunduh dari: http://massbfc.org/leadingOrgs.html.

18. Tesorio J. Filipina : pemerintah vs perusahaan susu formula. [edisi April 2007]. Diunduh dari: http://www.asiacalling.kbr68h.com.i ndex.php/archives/.

19. Redaksi. 3.869 ibu di Filipina susui bayi secara serentak. Republika online [edisi 06 Mei 2007]. Diunduh dari: http://www.republika.co.id.

20. AP. Japan scaps plan to urge breast-feeding. Diunduh dari: http://www.wtopnews.com.

21. Bartington $\mathrm{S}$ et all. Are breastfeeding rates higher among mother delivering in baby friendly accredited maternity units in the UK. Int. Journal of Epidemiology. 2006; 35: 1178 - 86.

22. Tri. RDPU komisi VII DPR dengan PERSAGI, PERGIZI PANGAN, PDGMI, dan BKPP-ASI. [edisi 2004]. Diunduh dari: http://www.gizi.net/egi-bin.

23. KCM. Turun, jumlah bayi yang dapat ASI eksklusif. Keluarga sehat.com 2007. [edisi 2007]. Diunduh dari: http://www.keluargasehat.com/keluarga.

24. Menkokesra. Mandek, pembahasan pengaturan pemasaran susu formula. Jakarta: Menkokesra; 2007 [edisi 2007]. Diunduh dari: http://www.menkokesra.go.id.

25. Tri. Rekomendasi pemasaran PASI diabaikan. Jakarta: Harian Kompas; 2003 [edisi 2003]. Diunduh dari: http://www.kompas.com. 